\title{
Not by human seed but born from above to become children of God: Johannine metaphor of the family or ancient science?
}

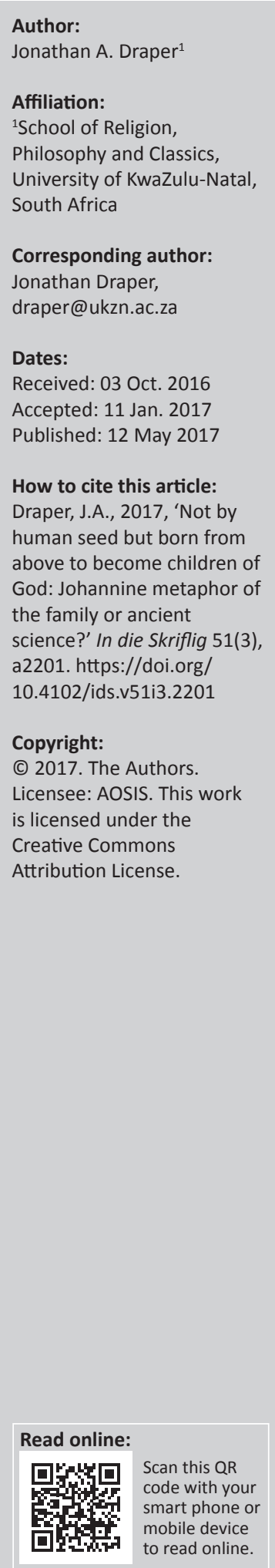

This article provides a critical reflection on Jan van der Watt's theory of the network of the metaphor of the family in John's Gospel, taking the Johannine understanding of the seed as a case study. In his reflections on God's act of creation, Philo uses the language of impregnation and (re)birth of the natural man by his divine seed to produce children of virtue for those who open themselves to divine wisdom. His Middle-Platonic construction is unlikely to have been understood as 'absurd, irrelevant or untrue', which characterises a metaphor in Van der Watt's definition. The discourse on the relationship between seed/sperm and life reflects ancient 'scientific' understanding of the world for Philo and John's Gospel. This article analyses the connections and differences between Philo's conception and the mysticism of John's understanding of rebirth from above as contrasted with 'natural' birth.

\section{Introduction}

In the incident where the Greeks ask to see Jesus, they are answered enigmatically with the riddling metaphor in John 12:24: 'Unless a grain of wheat falls into the ground and dies, it

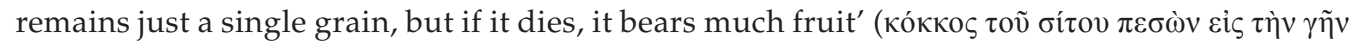

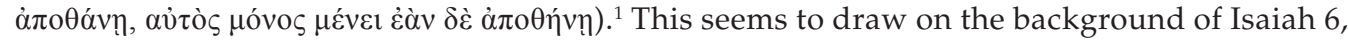
where a holy seed will remain after Israel is destroyed to renew the covenant and inherit the land again which is reflected in several manuscripts of the Septuagint ( $\sigma \pi \varepsilon \dot{\varepsilon} \rho \mu \alpha$ ó $\gamma 10 v \tau$ ò $\sigma \tau \eta \dot{\lambda} \lambda \omega \mu \alpha$ $\alpha$ vं $\tilde{s}$ - LC, Origen adds in his Hexapla sub asteriscus) ${ }^{2}$ (Draper 2000). Targum Jonathan ${ }^{3}$ refers this to the return of the diaspora, conflating the idea of the seed of a tree with the seed of human beings and John seems to have drawn on the same understanding of Isaiah. Jan van der Watt (2006) uses this metaphor of the grain of wheat falling into the ground and dying as a case study of metaphor in his paper, 'Ethics alive in imagery'. This has stimulated me to revisit my study of 'seed' in John on a broader canvas in this tribute to Van der Watt's sustained and insightful study of John's Gospel, since there is no doubt that this is a metaphor in his terms (seeds of plants and seeds of human beings are set alongside each other to interpret each other) and that it is networked into a larger construction of metaphors in the narrative of John. Meaning from the life cycle of plants is 'carried over' into the life cycle of human beings as understood by the Johannine Jesus. ${ }^{4}$ Just as Jesus must die on the cross before springing to glorious life again to bear fruit in many believers, so those who believe in Jesus may lose their life in one sense, but they will obtain it in a far more glorious form. But would this half of the meaning transfer have been understood in a defining way as contrafactual as Van der Watt claims? My interest is to question whether 'all is metaphor' or, to put it differently, at what point does John cease to speak metaphorically. ${ }^{5}$ For instance, could John have understood, as a given, that there was a universal biological material inherent in the specific seed of both plants and human beings which originates from the divine seed and so spans and enables the continuity of all material life, but is not confined by it? If he did, would it change the way we read his metaphor? How would this relate to John's understanding of the person and work of Jesus?

1.All quotations from the Bible in English are taken from the New Revised Standard Version (NRSV). All quotations and references to the Greek text are taken from Nestle-Aland (2013).

2.All references to the Septuagint are taken from the revised edition of Rahlfs and Hanhart (1949).

3.All references to the Targum of Isaiah are from Stenning (1953).

4.This is indeed the root meaning of the word $\mu \varepsilon \tau \alpha \varphi \rho \rho \alpha$ according to Liddell and Scott (1968:1118), which can refer literally to 'transport, haulage', as well as 'transference of a word to a new sense, metaphor'.

5.The questions raised here do not depend on whether the specific analysis of my earlier study with regard to John's use of Isaiah 6 is correct or not, it simply provides the point of entry to the current article. Note the broader discussion of the figurative and literal nature of metaphors in Volker Rabens' monograph (2013:43-54) on Paul and Philo. 


\section{The dying and rising seed in John 12:24-26}

Van der Watt understands the heart of the image in 12:24-26 in terms of process: in successive verses there is an entity (seed or person) which dies (hates life or serves) and produces a desireable result (much fruit or eternal life or honour from the Father). In this way the disciple becomes like Jesus. However, this may be missing John's point at an even deeper level: when read from a Middle-Platonic perspective the seed both dies and does not die because it bears the life principle within itself from creation by the Logos, because that is the nature of all seeds, animal and vegetable. Van der Watt (2006:437) himself notes that the literal death of the seed 'is not attested in the ancient world, not to mention that it is no longer accepted today'. However, it can be questioned whether the author of this gospel 'accepts it as a given' that the seed dies literally (Van der Watt 2006:437). I am not sure that it is so simple. In fact, the point of the saying may well lie in a generally accepted knowledge of the time that a seed dies at one level but not at another. My reservation rests on the basis of John's consistent use of language: he differentiates $\psi v \chi \eta$ fundamentally from $\zeta \omega \eta$, as is quite clear from his use of these terms in chapter 10. In 10:11, 15, 17, 24 Jesus repeatedly indicates that, like a good shepherd, he lays down his $\psi v x \eta$ ' for his sheep. However, this is a kind of life which he can lay down and take up again, because he is and mediates a different kind of life:

For this reason the Father loves me, because I lay down my life ( $\left.\psi v \chi \eta^{\prime}\right)$ in order ot take it up again No one takes it from me, but I lay it down of my own accord. I have the power to lay it down and I have the power to take it up again. (10:17-18)

The seeming contradiction of this statement is resolved in John 10:

My sheep hear my voice. I know them, and they follow me. I give

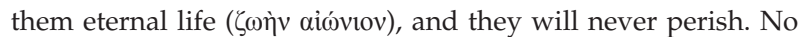
one will snatch them out of my hand. What the Father has given me is greater than all else, and no one can snatch it out of the Father's hand. The Father and I are one. (v. 27)

The same careful distinction can be seen in the saying concerning the dying and rising seed in 12:24-26.

What the Father gives Jesus, and Jesus gives his disciples beyond what is shared by the whole created order - is not $\psi v \chi \eta ்$ but $\zeta \omega \eta$, not the ephemeral natural existence inhering in all material creatures, but the enduring life principle within the ephemeral which comes from the Father and creates and sustains the world in its existence through the infusion of the Logos or life through the кó $\sigma \mu$ os. This is precisely the direction of what follows the metaphor of the seed falling into the ground and dying which we have been exploring in 12:25:

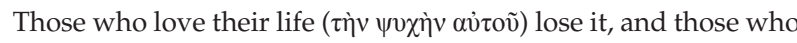

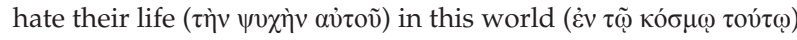

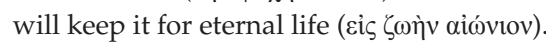

6.Further references to the Gospel of John will be indicated only by chapters and verses.
The language of the кó $\mu$ o $\varsigma$ is not accidental, but signals the $\psi v \chi \eta$ as the tenuous form of life which the whole created order shares with Jesus as the Logos incarnate. Since all things come into being through the Logos they share in the Logos and hence have the life principle within them in the form of seed in some fundamental way, I would argue that, in

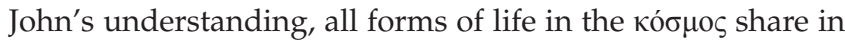
this life as $\psi v \chi \eta$. It is life subject to death and decay, and yet still mediates continuing life through its inherent seed. This is clear already from 1:4 in the Prologue. Jesus as the Logos has the life principle within himself from the Father - indeed

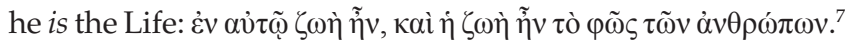
While all creatures share the Life proceeding from the Logos in a diminished form as $\psi v \chi \eta$, human beings have the potential

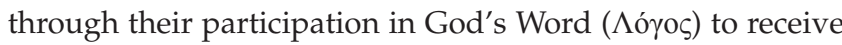
the Life principle itself within them from the $\Lambda$ ó ${ }^{\circ}$ s who is the $\zeta \omega \eta$, the $\varphi \tilde{\omega} \varsigma$ which shines in the darkness and cannot be extinguished (1:4) - as we shall see. This is not something human beings receive by nature, but something which they

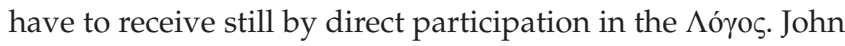
uses the metaphor of this kind of life as Light, which shines in the darkness whether people's eyes are open or not and whether they come to it or not. What he gives to those who are his disciples is to have this life principle within them also

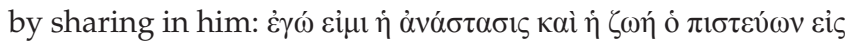

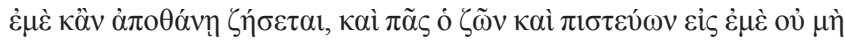

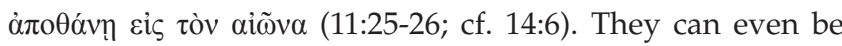

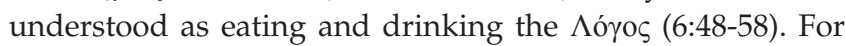
the metaphor of the seed to have its full impact, its implied hearers or readers have to have some knowledge of the Stoic and/or the Middle-Platonic worldview in which the world of phenomena is infused with the seed of the divine $\Lambda$ ó ${ }^{\circ}$ which continually regenerates the material world. However, human beings can aspire to the world of the spirit and choose, like Plato's philosopher, to leave the cave of Plato's Republic VII and its shadows and walk out into the Light in the world of true forms, entering a higher plane of existence through participation in the Logos.

The point, then, of the metaphor of the seed falling into the earth and dying, is that, even though the seed dies in one sense, in another sense its continued life is guaranteed because of the presence of the life principle or $\Lambda$ ó

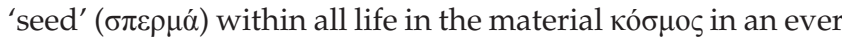
diminishing stream of being. Hence, contrary to Van der Watt's assertion (2006:437), the meaning of John's metaphor does indeed depend on the contemporary acceptance of 'the general validity of such a presupposition'. Indeed, the general permeation of the natural world by the seed of the $\Lambda$ óyos, which sustains, regenerates and orders all things, was one of the most widely accepted scientific propositions of the Stoics developed in a Platonic direction by the MiddlePlatonists of John's day as represented in his contemporary Jewish world by Philo of Alexandria. ${ }^{8}$ There is every

7.The connection between light and Logos goes back ultimately to Plato, Republic Book VII, but draws into itself the concept of 'Light' as the spoken Word in the account of creation in Genesis 1:3. For a discussion of this see Draper (2016).

8.This is not to argue that John knew Philo's work, but simply that these ideas were abroad in his world. 
likelihood that John (coming, in my opinion, from the multicultural Hellenized Jewish - probably priestly - elite in Palestine) was not only aware of this Hellenistic conception, but accepted its propositions himself, though he also developed and modified them by his understanding of the book of Genesis (Draper 2016). This forms the backdrop to his understanding of the person and work of Jesus and its consequences for those who believe in him. This is not an uncritical adoption of Hellenistic ideas, but one fundamentally transformed by the Jewish Scriptures. ${ }^{9}$

Although John does not use the word $\sigma \pi \varepsilon \rho \mu \alpha$ in his appropriation of the image of the seed in 12:25, but rather ко́ккоร, specifically used for 'grain' or 'seed of plants' (Liddel \& Scott 1968:971), it lies behind his thinking as can be seen in the Prologue:

He came to what was his own, and his own people did not accept him. But to all who received him, who believed in his name, he gave power to become children of God, who were born, not of blood or of the will of the flesh or of the will of man, but of God (1:11-13).

In light of our observations concerning the metaphor of the seed in 12:24-26, what exactly does John mean by human beings becoming 'children of God' without the natural assistance of a human father (or mother), and hence without specific human seed or sperm ( $\sigma \pi \varepsilon \rho \mu \alpha)$, which they had, in any case, within them? How was this conception and birth mediated in John's understanding? Would such a birth have been understood as 'contrafactual' (as Nicodemus indeed wrongly considers his language to be in 3:4), but having a meaning through its incongruity as Van der Watt argues? Is John's meaning metaphorical in this sense or does it follow a path of cosmology and ontology understood by John and his contemporaries as 'scientific' in a way which is simply different to our own cultural universe of meaning as to what constitutes science. In this case the term metaphor either does not apply or else must be defined differently. Jan van der Watt, in his groundbreaking monograph on metaphor in John's Gospel, Family of the King: Dynamics of Metaphor in the Gospel according to John (2000), argues that the contra-factual metaphor of birth ơ $v \omega \theta \varepsilon v$ establishes a 'theory of knowledge' in which, 'Proper revelatory knowledge requires spiritual sensitivy' which contrasts the earthly and spiritual levels (2000:171). In other words, to be born from above 'can only be experienced by a person (3:8) and cannot be explained in natural terms as Nicodemus endeavours (3:4)' (Van der Watt 2000:173). This all makes good sense in our postEnlightenment Western culture of Immanuel Kant's contrast of 'practical reason' and 'pure reason' of the empirical and the numinous, but it is not the only way of reading this birth 'again/from above'.

A second line of thinking is suggested by the interpretation of Paul by Troels Engberg-Pedersen's Cosmology and Self in the

9.1 have used this expression, with trepidation, because the term Hebrew Bible implies a fixed corpus and is not approprian, and also because it is a matter implies a fixed corpus and is not appropriate and also because it is a matter of debate whether John did or did not use the Greek Septuagint rather than Hebrew texts. I am moreover aware of the debate over the use of the term 'Jewish' in the 1st century $\mathrm{CE}$, but perhaps it is inevitable here.
Apostle Paul: The Material Spirit (2010; cf. Barrier 2014) that Paul understood the Spirit or spirit to be in some sense material. The $\Lambda$ ó $\gamma \circ$, in this way of thinking, is not 'spiritual' as opposed to material in Van der Watt's sense. EngbergPederson's hypothesis has been strongly contested by Volker Rabens (2013), among others, but the debate has shown that it is possible to understand Paul in this way. A consequence of such an understanding would be that the kind of seed sown in Jesus' followers to produce eternal life was spiritual, but also in some sense material or at least 'bodily' however strange it sounds to us, and however difficult it was even for Paul to explain it - significantly using the metaphor of seeds and sowing:

So it is with the resurrection of the dead. What is sown ( $\sigma \pi \varepsilon i ́ \rho \varepsilon \tau \alpha \mathrm{l})$ is perishable, what is raised is imperishable. It is sown ( $\sigma \pi \varepsilon i ́ p \varepsilon \tau \alpha$ ) in dishonour, it is raised in glory. It is sown ( $\sigma \pi \varepsilon i ́ \rho \varepsilon \tau \alpha)$ in weakness, it is raised in power. It is sown ( $\sigma \pi \varepsilon i ́ \rho \varepsilon \tau \alpha 1)$ a physical body, it is raised a spiritual body. If there is a physical body, there is also a spiritual body. (1 Cor 15:42-44)

Does this imply that animate physical bodies, including the ко́кко of wheat, have some corresponding spiritual properties though not destined for the glory Paul sees for the future regenerated spiritual body of believers, or is he speaking purely metaphorically in Van der Watt's sense? This article will briefly explore both options before undertaking a brief comparative exploration of the trope of

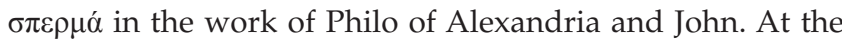
heart of the matter is the understanding of the creation and interpenetration of all things by the divine $\Lambda$ ó principle of hierarchies of being. Engberg-Pederson's hypothesis has been taken further in a thorough going Stoic interpretation of John's Gospel by his student Gitte BuchHansen (2010), whose work will be engaged below. While her rich and insightful study is illuminating in many respects, I do not find Buch-Hansen's claim (2010:30-31) that 'the Fourth Gospel can ... be read as a story in which the protagonist is no longer Jesus Christ, but the divine $\pi v \varepsilon \tilde{v} \mu \alpha^{\prime}$

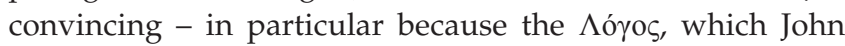
specifically highlights in his Prologue, all but disappears from view in her analysis.

\section{The nature of metaphor and the $\sigma \pi \varepsilon \rho \mu$ ó of the Family of the King}

Despite acknowledging the methodological problem of applying modern theories to an ancient text, such as the Gospel', Jan van der Watt (2000:xx) prefaces his discussion with the 'simple' assumption that an expression is either figurative or understood literally, so that, 'A metaphor is created when the literal meaning of a word in the sentence is absurd, irrelevant or untrue, while the sentence may nevertheless have a useful content' (2000:7, citing Mooij 1976). This determines his assumption that conception and birth by the Spirit is a metaphor since it is placed alongside literal earthly birth as contra-literal (hence 'absurd, irrelevant or untrue ... but having useful content') so that, 'This parallel use supports the idea of metaphorical application' (Van der Watt 2000:172). This has important repercussions, since, if the 
conception and birth 'from above' are conceived as metaphorical in this sense, then this supports ad initio from the Prologue onwards the hypothesis that the Family of the King can serve as the key to build and understand the network of 'contrafactual' metaphors which he argues inform the Gospel of John. Metaphor, he (Van der Watt 2000) argues in his book, consists of an 'analogy' between 'everyday life' and the 'spiritual':

By analogically linking widely accepted conventions from everyday life to what happens to the believer spiritually when he is born of God, received eternal life, becomes a child of God etc., John succeeds in utilizing established and generally accepted knowledge related to family life for understanding and explaining salvific and ethical events on a spiritual level. (p. 163)

Van der Watt's meticulous study enables the reader to look at John with new eyes through his relentless focus on interlocking metaphors relating to family. Metaphor becomes a hermeneutical key, but not an unproblematic one as he defines it. In particular, his usage produces a dualism between facticity and contra-facticity, or else between 'generally accepted knowledge' and 'the spiritual level' as in the passage above. Who determines what is 'fact' or generally accepted (by whom?), and what is contra-factual or absurd (to whom?)? While Van der Watt is aware of the importance of the context of the text in terms of socio-historical details, he does not take account of the larger 'social construction of reality' to use Peter Berger and Thomas Luckmann's terminology (1966) in which what appears absurd to us is supplied hegemonically (i.e. unawares) by our social and cultural horizons. Our own social universe of meaning determines how texts would have appeared when read in their own context and how they should be interpreted in ours, unless we undertake the kind of painstaking phenomenological observation and 'thick description' suggested by Clifford Geertz (1973:3-30) which enables us to distinguish between a twitch and a wink. Would John's (implied) readers have considered it absurd for 'birth from above' to have been produced by a new infusion of divine seed or sperm by the creative $\Lambda$ ó $\gamma$ $\varsigma$ which resulted in a new kind of inextinguishable life inhering within the biological life of a follower of Jesus, but continuing beyond it? Is it for them simply a literary metaphor for obtaining a new spiritual identity in a new community as 'they share the qualitative life Jesus brought from God' (Van der Watt 2000:178)? What is a 'spiritual reality' (Van der Watt 2000:171)? Is the Johannine irony, which is produced by the 'two level drama' (as argued, e.g., by Kowalski 1996), merely a matter of the literal versus the metaphorical, or would it have been understood as a play between two levels of reality, between two kinds of life produced by two different kinds of insemination?

These questions become important, since conception and birth occupy a key place in Van der Watt's discussion (2000:161) of the Family of the King as metaphors among those which 'are not found in one contextual location ... but are spread throught the entire Gospel'. Indeed, Van der Watt (2000) sees birth as the beginning of life to be determinitive for the creation of the family metaphor:
Being born, leads to life. Life and birth not only belong to the same field of imagery, but are also conceptually linked in the Gospel. This makes the construction of a larger metaphor network possible. Birth initiates life, and life is the corollary of birth. This reference to birth thus opens up the potential application of the wider imagery of the family (with God as Father) and thus the creation of a metaphor. (p. 186)

Certainly, family and family metaphors interpenetrate John's Gospel and Van der Watt has identified a key marker, but one might ask whether the idea of divine seed, divine conception and divine birth would have been seen as 'absurd, irrelevant or untrue' in the world of Hellenistic Jewish thought in which John moved. Is birth 'in the Spirit' the same as 'spiritual birth' or 'metaphorical birth'? It appears that way within the Western post-Enlightenment materialistic scientific worldview that determines what appears 'natural' to scholars working within that framework. For instance, in the West biological birth through conception by a mother and a father is assumed to make one a member of a family automatically, such that if genetic profiling proves the biological fatherhood of a man, he would be obligated to provide for his baby even if he is prohibited from access to it. Likewise, conception and/or birth make one a human being with rights and privileges. These are, however, not universal understandings at all. As Kenneth Mtata (2015:243) observes, 'In many African cultures, children go through various personhood attainment rituals in order to become fully human' (cf. Nasimiyu-Wasike 1992). ${ }^{10}$ This has the potential to lead to the abuse of children before puberty, since they are not understood yet as 'fully human' and therefore they do not necessarily receive the same burial. ${ }^{11}$ In this sense it is the introduction to and acceptance by the ancestors that makes a person a member of a family in many African cultures. Similarly, it was not conception and birth that made one automatically a member of a family in Roman culture, ${ }^{12}$ since a new born child might be exposed in the market place, left either to die or to become a slave. Such a child would by no means be regarded as a family member in any sense if the pater familias did not accept it, whereas slaves might be regarded as, in some sense, family members who could not 'unfamily' themselves even after they were emancipated.

Of course, Van der Watt (2000:162-168) is aware of the importance of such differences in culture between the ancient world and his own (Western) world with respect to family structures and life, referring the reader to key studies in the field. However, he sees the value of such 'external social information' only in confirming what has been obtained already by a text immanent reading. The danger of this procedure is that the Vorverständnis of the reader concerning

10.This is a matter of considerable debate in African theology, but the consensus is that some form of communal identity construction through socialization by rituals and acceptance by the ancestors is an important aspect of the African universe of meaning. Kenneth Mtata's excellent study (2015) sets out the debate and the shifts of emphasis, together with an emerging consensus, it has seen. Connection with the world of the spirit in traditional Zulu culture, at least in important aspects, is 'spermatic' one, mediated through biological lineage (see Draper 2013a).

11.Again, this is a matter of considerable debate into which this article cannot enter.

12.Research into the nature of the Roman family has been the subject of many important studies in recent years, such as Osiek (1996) and the papers in Balch and Osiek (2003) 
what is 'natural' and what is 'absurd' already determines the results unless it is interrogated at the outset. Conversely, the danger of beginning with the (reconstructed) ancient social context is that the (incomplete) historical data, provided by the text, may be made to fit the (hypothetical) model. The problem is complex and goes to the heart of the hermeneutics of reading. ${ }^{13}$ It cannot be solved here. This article simply argues that the properties of seed, conception and birth, which seem obvious enough to a modern scientific worldview, lie at the heart of a very different scientific conception of the ancient Graeco-Roman world that may underpin the worldview and therefore the narrative of John's gospel. This Hellenistic universe of meaning was a contested one at the cross-roads of East and West in the ancient world. It is this contestation of reality, rather than agreed contra-facticity, that provides the pervasive irony that characterises John's Gospel. While applauding the achievement of Van der Watt's work on metaphors in John, we are concerned here simply to explore the limits of a modern literary trope within narrative methodology for the interpretation of a complex ancient text.

\section{Implications of a material conception of Spirit, Divine Seed and Logos}

A confirmation that contemporary 'science' in the ancient world considered $\pi v \varepsilon v \tilde{\mu} \alpha$ to be, in some sense, a material substance (albeit invisible), which is conveyed through the $\sigma \pi \varepsilon \dot{\rho} \mu \alpha$ in procreation to bring life, is found above all in the medical writings of Galen (129-c199 CE; see especially, De

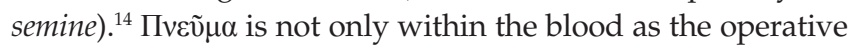
principle within the body, but can pass in and out through the bodily orifices. Outside the body it is found as air (án $\rho)$ and is breathed in to the human body where it is refined into

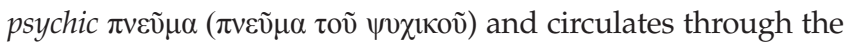
body vivifying its organs. It is the presence of the life-giving $\pi v \varepsilon \tilde{v} \mu \alpha$, contained in the human sperma, that facilitates human reproduction (Barrier 2014:6-9). For Galen, scientific medical knowledge needs to be studied alongside philosophy (see especially his Si quis optimus medicus est, eundem esse philosophus), so that essentially theological ideas were understood as grounded in and interactive with scientific observation. I am not so much interested here in the specifics of Galen's theory as in the fact that the presence of the pneumatic life force within the seed in reproduction was not seen as metaphorical, but as 'scientific' and as interrelated with worldview, that is, theological debates and understandings about the world, God and Spirit or spirit. Galen was a follower of the Platonic

13.Rabens (2013:43-54; cf. pp. 84-86, 102-119) in addressing the same questions raised in this article concerning the materiality of spirit, though in relation to Paul, provides a helpful discussion of metaphor. He rightly points to the importance of context: context of utterance, culture and reference. In the case of John's Gospel, am particularly concerned with the way in which, what an ancient culture treated as 'science', may be treated by modern scholars as 'metaphor' and thus create a hermeneutical mismatch. Would modern interpreters regard modern science as 'metaphorical'?

14. My attention was first drawn to Galen by a paper given by Jeremy W. Barrier (2015) at the 17th International Conference on Patristic Studies in Oxford. I am grateful to him for providing me with a pre-publication copy of this paper, together with his published article Galatians (Barrier 2014). I draw on Barrier's work in this section of my article, though he is not responsible for my reflections on it! The English text my article, though he is not responsible for my reflections on it! The English text
used here is that of John Redman Cox (1843) The Greek text used is drawn from used here is that of John Redman Cox (1843)
Thesaurus Linguae Graecae (TLG) online. philosophical school. One could thus argue that in these terms, while Jesus's dying and rising is not the same as a grain of wheat falling into the ground, dying and growing, and to that extent 12:25 is a metaphor, nevertheless something more is going on there that relates to the understanding of the $\Lambda$ ó $\varsigma$ and the life principle in the ancient world. There are hierarchies of seed, but the same ever-diminishing (divine) life principle inherent within the material world. There is a hierarchy of being, but all of it derives from and is sustained in life by the seed of the $\Lambda$ óros.

Being born from above ( $\alpha \nu \omega \theta \varepsilon v)$ to become a child of God, among many children of God ( $\tau \dot{\varepsilon} \kappa v \alpha \theta \varepsilon \circ \tilde{u})$, was not necessarily simply a metaphor for being saved and joining the Johannine community although it clearly has that dimension. It seems more likely that John had a deeper 'scientific' understanding connecting this conception and birthing with Jesus as the

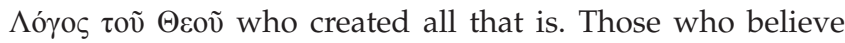
in Jesus have the divine $\pi v \varepsilon \tilde{v} \mu \alpha$ breathed into them (20:22)

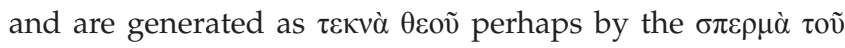
$\theta \varepsilon \circ \tilde{v}$ (implicit but not part of John's terminology) deriving

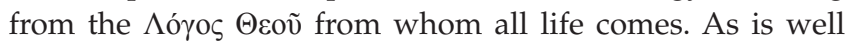
known, this theme of conception and birthing emerges again particularly in the story of Nicodemus, whose visit to Jesus by night calls forth the rude comment from Jesus: 'Very truly, I tell you, no one can see the kingdom of God without being born from above' ( $\gamma \varepsilon v v \varepsilon \theta \tilde{n}$ ö $v \omega \theta \varepsilon v-3: 3) \cdot{ }^{15}$ Nicodemus points to the impossibility of going back into the mother's womb for the opportunity of a second birth, to which Jesus responds that to be born from above means birth by '[water and ${ }^{16}$ the Spirit' (3:5-8). In 3:15-16 Jesus refers to his lifting up on the cross as the means by which this new kind of life will be mediated when the Spirit is transmitted ${ }^{17}$ at his death (19:30)

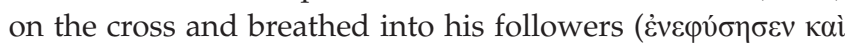

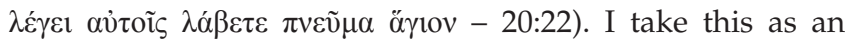
answer to Nicodemus' question, 'How can these things be?' (3:9), which is more direct than indirect. As in 12:25, the new birth is linked with 'being lifted up' on the cross, that is, through Jesus' death in the same fashion as the seed that falls into the ground. Jesus, in other words, implies that there is a kind of holy seed from which the new children of God will be born from above. It implies an impregnation and birthing process that is related to (since human beings are created by

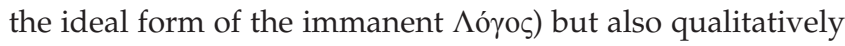
different from human sexuality and childbirth (since, in this case, the life comes directly from the incarnate $\Lambda$ ó Human $\sigma \pi \varepsilon \dot{\rho} \mu \alpha$ is contrasted with divine $\sigma \pi \varepsilon \dot{\varepsilon} \mu \alpha$ as in Philo

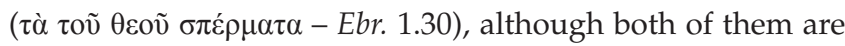
understood as coming from the $\Lambda$ óyos from whom all life comes in a hierarchy of being.

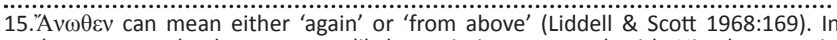
the context, the latter seems likely, as it is contrasted with Nicodemus misunderstanding of what Jesus says to refer to re-entering the mother's womb.

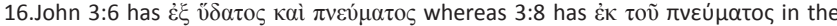
parallel phrase (with only Codex Sinaiticus, the Old Latin and Old Syriac versions mirroring - v.6). If the phrase of water refers to baptism, as some have suggested it would remain the act of faith and the operation of the Spirit which effects the participation in regeneration and not the ritual itself (see the discussion in Belleville who sees here an echo of Ezk 36:25-27).

17.The Greek word $\pi \alpha \rho \alpha \delta i \delta \omega \mu$ c can mean 'give', 'hand over', 'transmit' and obviously does not mean simply 'died' (Liddell \& Scott 1968:1308). 
The hypothesis, which I am testing here in a somewhat preliminary way, is that Jesus as God's $\Lambda$ ó $\varsigma_{\text {, }}$, the creative principle through which something other than God comes into being, is understood in the kind of way that Philo of Alexandria also understands it. In a neo-Platonism influenced by Stoic ideas, the creative principle of the divine $\Lambda$ ó understood as the holy seed or $\sigma \pi \varepsilon \dot{\varepsilon} \mu \alpha$ inherent in the created order (for Philo through the twin principles of creative and legislative power). The material and spiritual seeds were not understood as opposites but cognates; not as contra-factual but as a scientific and philosophical proposition about the way things really were. I propose to explore briefly the concept of holy seed or $\sigma \pi \varepsilon \dot{\varepsilon} \mu \alpha$ in Philo as an interpretive lens on John's use of the same trope, since Philo, as a Hellenised Jew immersed in Torah and simultaneously in Greek philosophy, stands far closer to John's Gospel than Galen. Of course, Philo works on the Pentateuch as allegory, but by that he does not mean something approaching contra-factual metaphor. Rather, he argues that the deeper level of meaning underneath the narrative is in harmony with rational Hellenistic philosophy and 'science' - indeed, that Hellenistic philosophy and 'science' was already prefigured in the writings of Moses. Comparisons of John with Philo of Alexandria are, of course, not new. The research of E.R. Goodenough (1935) opened the way, while C.H. Dodd (1953) in his ground-breaking The Interpretation of the Fourth Gospel further charted this course (more recent studies have included Leonhard-Balzer 2004; Borgen 2014; Draper 2016; cf. Decharneux 1994).

The most extensive and consistent recent attempt to compare Philo with John's Gospel has been made by Gitta Buch-Hansen (2010). Buch-Hansen (2010:31) argues in her own summary on the basis of this comparison that it is the 'meta-narrative' of John in which 'Stoic physics is the glue that makes this version of the Johannine story a coherent narrative'. The narrative consists of a series of four pneumatic transformations of Jesus: First, Jesus is transformed through

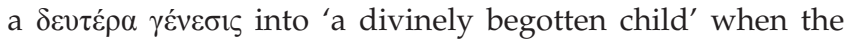
Spirit comes down and remains on him at his baptism as attested by John the Baptist (1:32); second, the Spirit is 'embodied' in Jesus' words and deeds (as signs) leading up to the cross; third, the resurrection climaxes in the ascension and translation of Jesus into pneumatic Father (13:1, 20:17); and finally, believers are regenerated by 'from above' $(3: 3,5)$ through 'the infusion of the Holy Spirit' (20:22) in the same way as Jesus. In the end, 'no ontological difference exists between (the flesh-and-blood) Jesus as the Son of God and subsequent generations of believers as God's children ... Consequently, Jesus is himself among the spirit-born persons' (Buch-Hansen 2010:301-302).

There is no scope here to provide a detailed interaction with Buch-Hansen's hypothesis. In many ways, it is generated by the same impulse as this article, which I would affirm:

The way we automatically couple the physical with the real and literal and the cognitive with the metaphorical and spiritual is the result of post-ancient, Cartesian categorizing. But the predicates of the real and the image-metaphorical-spiritual are not a priori connected with the experience of the physical world and cognitive activities, respectively. Instead, the distribution of these predicates is the result of a discursive struggle about how to interpret and evaluate our experience. (Buch-Hansen 2010:201)

However, if I may preface my own discussion with my reactions to hers, I see Philo as fundamentally located in a Middle-Platonism that affirms the creation of the world by a transcendent God through his $\Lambda$ óyos, and rejects monism and the Stoic idea of conflagration (Runia 1981). Therefore, it does

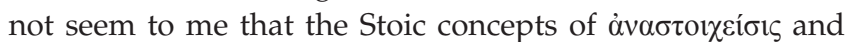
$\kappa \rho \tilde{\alpha} \sigma ı \varsigma$ play the kind of role in his work that Buch-Hansen envisages. Certainly Philo engages in special pleading with regard to the ascension to heaven of his hero Moses (and to some extent with other biblical figures), but the idea of Moses becoming translated into God through an infusion of spirit, is alien to his system. Likewise, John is closer to the MiddlePlatonism represented by Philo than to Stoic monism. The Spirit or Paraclete in John, as Rabens (2012:117-120) has pointed out, is 'modelled on Jesus' and mediates his presence. ${ }^{18}$ It must be added that the Paraclete's role in John 14-16 is not translating or blending into spirit, but reminding his own of Jesus' words, convicting the world of sin, righteousness and judgement as well as defending them against the hostility of the world (which is nevertheless a world that God created and therefore loves enough to intervene again through his $\Lambda$ ó ${ }^{\circ}$ ) ). Nevertheless, the notion of $\delta \varepsilon v \tau \varepsilon \dot{\rho} \alpha \alpha \varepsilon^{\prime} v \varepsilon \sigma ı \varsigma$, drawn from Stoic physics but applied within a Middle-Platonic framework, does play a major role in Philo's thought and, I will argue, also in John's Gospel although in connection with the linked concepts of $\Lambda$ ó $\gamma$ s and $\sigma \pi \varepsilon \dot{\rho} \mu \alpha$ rather than $\pi v \varepsilon v \tilde{\mu} \alpha$ with respect to creation and the operation of the кó $\sigma \mu \mathrm{s}$.

\section{The holy or divine seed or sperm in Philo}

In opposition to those who say the world was not created, but had always existed, Philo, an Alexandrian Jew and a near contemporary of John, understands creation as a necessary

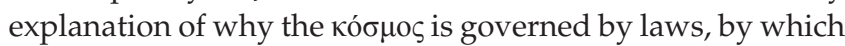
he understands both natural physical laws and also human cultural laws:

... embracing the creation of the world, under the idea that the law corresponds to the world and the world to the law, and that a man who is obedient to the law, being, by so doing, a citizen of the world, arranges his actions with reference to the intention of nature, in harmony with which the whole universal world is regulated. (De opificio mundi 1:3)

18. Here I agree with Voker Rabens, (2012:117) that "there is no evidence in John that the author shares the same interest in the ontology of the Spirit as the Stoics. We do not find any of the kind of discussions about the nature of $\pi v \varepsilon v \tilde{\mu} \alpha$ as we can see in Stoicism'. Rabens' main concern is with John's ethics rather than ontology, but there is obvious interest in John and Philo in the ontology of the $\Lambda$ ó $\gamma_{0} \varsigma$ linked already with

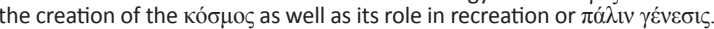

19.All quotations and citations of Philo are taken from the Loeb Classical Library text and translation. Some scholars have seen inconsistency in Philo in that he appears and to to accept the Arstotion De aeternitate mundi, but at this point philo was merely applauding Aristotle's piety and not his philosophical position which he rejects along with the position of the Stoa: see the authoritiative paper by David Runia (1981) based on an analysis of its form and structure. 
From here, he moves to understand seed or $\sigma \pi \varepsilon \dot{\varepsilon} \mu \alpha$ generated by the $\Lambda$ óyo and inhering as the life principle in every created being as the central element of creation and guarantor of the

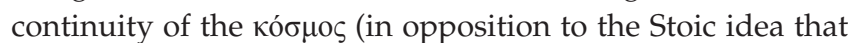
the world will be destroyed by a conflagration and then regenerated by the divine $\Lambda$ ó ${ }^{\circ}$ - an idea he opposes in De aeternitate mundi as we have seen). But there is a hierarchy of seed, from plants to animals to the last and 'best' which is the seed in the human being, since this is related more directly to reason and hence to the $\Lambda$ ó

Now seed is the original starting-point of living creatures ( $\tau$ ò

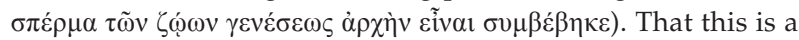
substance of a very low order, resembling foam, is evident to the eye. But when it has been deposited in the womb and become solid, it acquires movement, and at once enters upon natural growth. But growth is better than seed, since in created things movement is better than quiescence. But nature or growth, like an artificer, or (to speak more properly) like a consummate art, forms living creatures, by distributing the moist substance to the limbs and different parts of the body, the substance of life-breath to the faculties of the soul. Affording them nourishment and endowing them with perception. We must defer for the present the faculty of reasoning, out of consideration for those who maintain that it

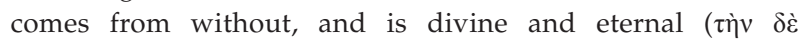

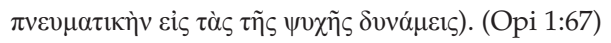

Nevertheless, as we see above, the seed needs a womb to generate into motion and become nature ( $\left.\varphi v \sigma_{1} \varsigma\right)$, requiring both the male and the female principle to become perfect in motion. Philo combines this originally Stoic concept of the $\Lambda$ óyos as the divine seed, pervasive in all that exists, with the monotheistic principle of creation through the Word spoken in Genesis. Philo, nonetheless, guards it against pantheism, in the first place, by differentiating the seed found in all life forms and the seed as it is found in human beings as rational and therefore partaking of the nature of $\Lambda$ ó $о$ s in a more fundamental way.

Within this, there is a patriarchal hierarchy between the male principle which is active and dominating and therefore represents the spiritual, rational principle, and the female principle, since women are sensual and passive and therefore represent the body which is to be subdued by the mind (Legum allegoriarum 2:37-38). However, what is significant for our discussion is that Philo highlights the active role of God in planting the divine seed in the virtuous women of the Septuagint as an allegory - not to be confused with metaphor in Philo - for it is the birth of wisdom and virtue in human beings that differentiates them from animals. God, as the unbegotten begetter, sows his divine seed ( $\tau \grave{\alpha} \theta \varepsilon \tilde{\alpha} \alpha \sigma \pi \varepsilon \dot{\varepsilon} \mu \alpha \tau \alpha$ ) in human beings not to bring forth children for himself since he needs nothing $(\dot{\eta} \delta \dot{\varepsilon} \sigma v \lambda \lambda \alpha \beta$ oṽ $\sigma \alpha$

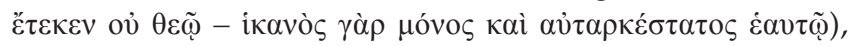
but to bring forth virtue to human beings by the divine life within them. Sarah and Leah (like Rebecca and Zipporah) conceive by God's direct action:

$\mathrm{He}$ is the father of all things, for He begat them, and the husband of Wisdom, dropping the seed of happiness for the race of mortals into good and virgin soil. For it is meet that God should hold converse with the truly virgin nature, that which is undefiled and free from impure touch; but it is the opposite with us. For the union of human beings that is made for the procreation of children, turns virgins into women. But when God begins to consort with the soul, He makes what before was woman into a virgin again, for He takes away the degenerate and emasculate passions which unmanned it and plants instead the native growth of unpolluted virtues. (De cherubim 50)

Philo is aware that this kind of talk may occasion either scandal or ridicule (because of its closeness to the discredited and often scandalous hieros gamos of the Graeco-Roman gods with humans) and begins by refuting the charge (De cherubim 1:42), but does not hesitate to argue that the divine seed is involved as a mystery in human intercourse in generating virtue without which human beings are incapable of conceiving anything (pp. 43-44).

Philo builds on this Middle-Platonist schema of the two fold seed (the universal seed in ordinary human sperm, which partakes in the Logos in a transient way similar to the animals, and the divine seed which is generated through co-operation between God as the impregnator and virtuous human beings as the recipients and beneficiaries) a certain mystical spirituality and religious practice favouring contemplation and ascent towards God. In this he draws on Plato's famous analogy of the cave in The Republic VII. The whole of De migratione Abrahami is devoted to the theme of turning away from the outward senses towards the inward appreciation of the world of the Spirit in order to become the seed promised to Abraham. The promise to Abraham that in his seed the nations would be blessed, becomes a promise to those who turn from the outward senses and allow the divine seed of wisdom (understood by Philo to be synonymous with the Logos) to be generated in them. So, the divine seed is not inherited by natural birth, but by turning to God and away from the prison of the body (Quis rerum divinarum heres sit 68) in a spiritual discipline of faith that approaches a frenzied ecstatic experience (p. 69). This ascetic practice is described in detail through his description of the community of the Therapeutae (real or imagined) in De vita contemplativa. Since the divine seed, which is eternal and the true heir of Abraham, turns away from the material to contemplation of the unknowable God, there is an element of hope for something eternal in the current life of those who practice this kind of spirituality. In all of this, it should not be overlooked that while the various schools of philosophy differed in their definition of the role of the Logos and its relationship to the divine seed permeating the cosmos, it was an attempt to explain the way the world came into being and how it functions in itself and with respect to human beings. To this extent, it is not metaphorical in the sense of what is viewed as contra factual, but 'scientific' in the sense of an explanation of the way things 'really are' even if allegories from Greek mythology or the Hebrew Scriptures might be used to explain it. 


\section{The Logos, the divine seed or sperm and human beings in Philonic terms}

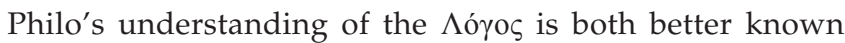
and perhaps more disputed than his understanding of the $\sigma \pi \varepsilon \varepsilon^{\rho} \mu \alpha(\tau \alpha) \theta \varepsilon o \tilde{v}$. It is, of course, material to this article, and yet it will not form the focus, which remains the nature of metaphor. From Philo's Neo-Platonic point of view, the $\Lambda$ ó os mediates the unknowable, immovable and unchangeable God:

'God is not as man,' but neither is he as heaven, nor as the world; for these species are endued with distinctive qualities, and they come under the perception of the outward senses. But he is not even comprehensible by the intellect, except merely as to his essence; for his existence, indeed, is a fact which we do comprehend concerning him, but beyond the fact of his existence, we can understand nothing. (Quod deus sit immutabilis 1:62)

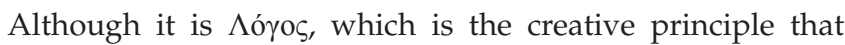
produces the $\kappa$ ó $\mu$ os, it remains at the level of the idea in the realm of the Spirit like that of a blueprint in the mind of an architect planning a city:

For God, being God, assumed that a beautiful copy would never be produced apart from a beautiful pattern, and that no object of perception would be faultless which was not made in the likeness of an original discerned only by the intellect. So when He willed to create this visible world He first fully formed the intelligible world, in order that He might have the use of a pattern wholly God-like and incorporeal in producing the material world, as a later creation, the very image of an earlier to embrace in itself objects of perception of as many kinds as the other contained objects of intelligence. (De opificio mundi 16-17)

This design, which pre-existed the creation of the кó $\sigma \mu \mathrm{s}$ itself, is, of course, mediated by the divine $\Lambda$ ó ${ }^{\circ} \varsigma_{\text {(o }} \theta \varepsilon$ cov $\lambda$ ó $\mathrm{o})$ :

Now if the part is an image of an image, it is manifest that the whole is so too, and if the whole creation, this entire world perceived by our senses (seeing that it is greater than any human image) is a copy of the Divine image, it is manifest that the archetypal seal (i் $\dot{\alpha} \rho \chi \dot{\varepsilon} \tau v \pi \circ \varsigma \varsigma \varphi \rho \alpha \gamma i \varsigma)$, also, which we aver to be the world descried by the mind, would be the very Word of God

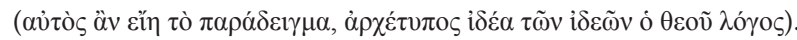
(De opificio mundi 25 )

Human beings were created in Philo's understanding on a different archetype from the other living beings, since God based their creation on the archetype of the $\Lambda$ ó ${ }^{\circ}$ for which reason they also received a (spiritual) soul:

That in soul also he was most excellent is manifest; for the Creator, we know, employed for its making no pattern taken from among created things, but solely, as I have said, His own

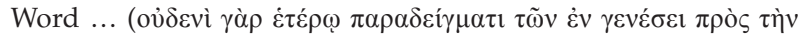

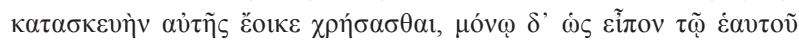
$\lambda \hat{o} \gamma()$. It is on this account that he says that man was made a

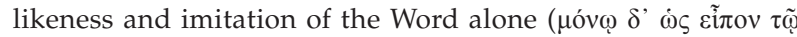
$\dot{\varepsilon} \alpha v \tau$ ov $\lambda$ ó $\gamma()$, when the Divine Breath was breathed into his face. The face is the seat of the senses. By the senses the Creator

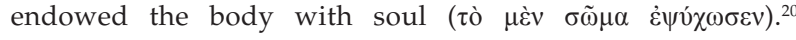
(De opificio mundi 139)

So, in some sense or another, every human being is created by

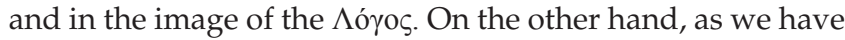
seen, Philo understands a further impregnation by the Logos of the 'pure womb' with the $\sigma \pi \varepsilon \dot{\varepsilon} \rho \alpha \theta \varepsilon$ ov in the righteous person that germinates to produce wisdom and virtue. This 'divine sperm' seems to form some kind of bridge between the $\Lambda$ ó ${ }^{\circ}$ s in the world of ideals and the Logos engendered in virtuous material human beings It moves beyond the human process of conception and birthing through natural sperm in the world of matter. This appears to be a sphere of ambiguity that Philo does not resolve, a hermeneutical gap for the reader today and probably an unresolved hermeneutical gap as much for a reader in Philo's own time as it was for Philo himself. ${ }^{21}$ The continuing influence of Philo's work or, at least, of the kind of thinking he represents, can be found at work in the concept of the $\lambda$ ó which shares some of the ambiguities of Philo himself (cf. Grillmeier 1975:89-94). Again, however, it is not presented as a metaphor - at least not a contra-factual one, but as a serious attempt to describe how a human being actually is in reality.

Located chronologically between Philo and Justin, I understand the Gospel of John as participating in the same thought world springing from Hellenistic Judaism and deeply influenced by Hellenistic philosophy, but taking a critical stance against it on the basis of the Hebrew Scriptures. I am also assuming that he is engaging with it at a fundamental level when he uses the concepts both of the masculine $\Lambda$ ó $\gamma$ (and not the cognate female Sophia/Wisdom), and the vocabulary of conception, birthing and the gender inclusive

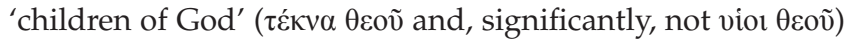
as well as the seed that falls into the ground and bears fruit. This will form the basis for my brief comparative discussion of John's Gospel.

\section{Logos, conception, birthing and offspring in John's Gospel}

It goes without saying that the $\Lambda$ ó o $_{\text {is }}$ an important feature of John's Gospel given its prominence in the Prologue that creates the 'two level drama' which informs and colours the entire narrative. There is no space in this article to discuss the further use of the term $\lambda$ ó ${ }^{\circ} \varsigma$ in the rest of the Gospel where it is not so prominent, but where there are signs that it continues to be used in a significant way as I have argued elsewhere (see Draper 2004 on 5:37-38; 2013b on Jn 15; 2015 on 10:34-36; 2016 on 1:1-14). John begins his account of Jesus with the pre-

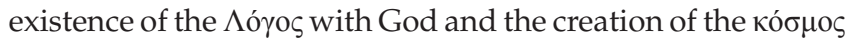
by the uttered $\Lambda$ óros: 'Let there be Light' into the chaos,

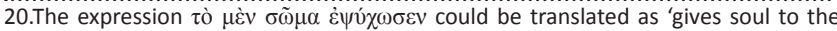
body' or 'gives life ( $\psi v \chi \eta$ ') to the body' through the Divine Breath of the Word/ Creator that was breathed into the face of the human being (see Liddell \& Scott 1968:2028).

21.David Runia (1986:337-338) sees the distinction between the two men as an ethical and based on Plato's Phaedra, with 'man according to the image' as an thical and based on Plato's Phaedra, with 'man according to the image' as an idealisation of man 'as he was created to be', but which can only be attained 'in eschatological terms' when he has left the body. However, the influence of the Stoic regeneration through the spirit does seem to influence Philo at this point. 
which brought all things into being, into life. What is striking is that this Light or $\Lambda$ ó divine fiat, but continues to shine ( $\varphi$ aival) in the darkness of the chaos that constantly seeks to overcome it, but never

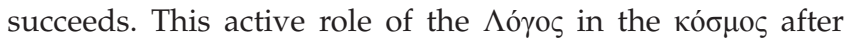
creation in John's Gospel seems to challenge the conception of the $\Lambda$ ó ${ }^{\circ} \varsigma$ as unknowable per se and restricted to the realm of ideas in the Platonic way that Philo conceives it. Nevertheless, John's notion of a visible light or glory, which

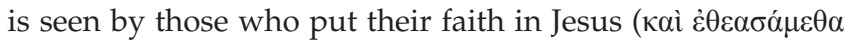

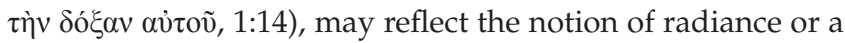

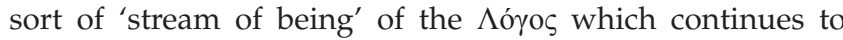
infuse the world of matter in the manner in which Philo sees God continuously impregnating the righteous with the divine seed of the $\Lambda$ ó

In fact, while the true light to which John bears testimony ( $\tilde{\tilde{\eta}} v$

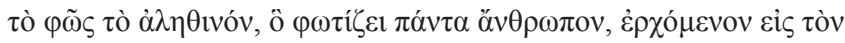

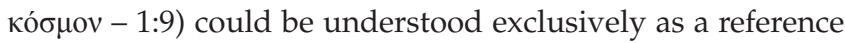
to the incarnation, this is not necessarily the only way of understanding it. If the present tense of 'shining' and 'coming' is given the weight of continuing action, beginning already from the creation by the $\Lambda$ ó $\varsigma_{\text {, the }}$ the the $\Lambda$ was doing this before the incarnation as the active agent in God's salvation history from the eternity. This is indeed how John perceives it, since Abraham, Moses, Jacob and Isaiah are all described as having seen Jesus. For John, every epiphany is a vision of the Light shining in the darkness: '[o $\Lambda$ ó

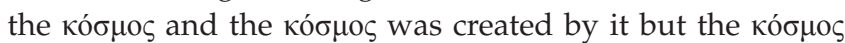
did not know it' -the situation prior to the incarnation. Indeed, when the $\Lambda$ ó ${ }^{\prime}$ s comes to his own creation, his own people do not accept him - as they should have done as those

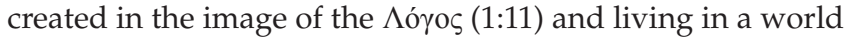
where everything is in some sense a reflection of God's

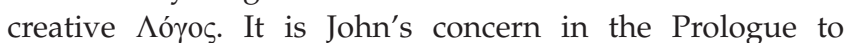
emphasise the continuity between this on-going presence of the divine $\Lambda$ ó ${ }^{\circ} \varsigma$ within the created order, already recognised by the Patriarchs of Israel, with the human Jesus.

Buch-Hansen (2010) sees the witness of John the Baptist to the coming and abiding of the Spirit on Jesus as the major marker in the text:

I have upgraded the Baptist's testimony from 'an index finger' to a testimony from which we may gain knowledge about the first pneumatic event in the signified story of pneumatic translations. John testifies to Jesus' divine generation through the descent of the spirit. (p. 224)

The discussion of Jesus with Nicodemus then represents the interpretation of the Baptist's testimony to refer to the moment of Jesus' transformation into spirit in a deutera genesis which is the pre-condition for those who believe in him to experience the same transformation. The discourse in 3:1-36 provides the 'hermeneutical key to the entire Gospel' (BuchHansen 2010:219, 276). Nevertheless, for her the regeneration of believers is only possible after Jesus' translation as spirit into the Father on his ascension, which is proleptically implied throughout, so that 'his whole journey is an extended ascension' (Buch-Hansen 2010:386). The problem with her analysis is that the Stoic 'meta-narrative' she sees in the text appears too complex to be plausible, turning on concepts not found expressly in John, and takes little account of the actual structure and narrative of the Gospel. ${ }^{22}$

Buch-Hansen is right in highlighting the cosmological importance of the Baptist's testimony and the dialogue between Jesus and Nicodemus, but wrong in detaching them from the Prologue and forcing them into a Stoic mould. They operate rather within a Middle-Platonic worldview similar to that of Philo - influenced but not determined by Stoicism.

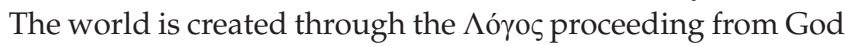
which continues to uphold and sustain all creation ('My Father is working and I am working' -5:17). All life proceeds from the $\Lambda$ ó $\varsigma \varsigma$ and it remains immanent in a diminishing stream of being in all living creatures through the divine

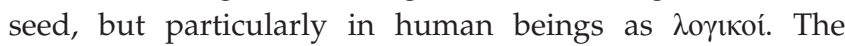
theophanies, experienced by the Patriarchs and prophets of Israel (e.g. Abraham, Jacob, Moses, Isaiah), were the operation of the $\Lambda$ ó ${ }^{\circ}$ to produce the 'second man' in a way similar to Philo's conception. However, the $\Lambda$ ó ${ }^{\circ} \varsigma$ then became flesh in human history in the human being Jesus as a new and direct regenerative act of God that constitutes a new creation through a second birth. John 3 uses the imagery of conceiving

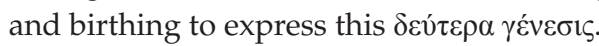

Nicodemus comes to see Jesus in the darkness, seeking light. He is immediately told that he needs to be born from above of water and Spirit or he cannot see the rule or economy of God. Here the female principle of womb, conception and birthing is invoked by John - with the water perhaps representing the breaking of the waters rather than baptism or perhaps baptism as a symbol of the breaking of the waters. But then, whose womb are we talking about? There is no mention here of virtuous widows or women beyond the

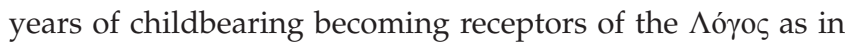
Philo. If the generative principle, the $\Lambda$ ó ${ } \varsigma$, is no longer conceived of as male, because it becomes flesh, then the womb and birthing of those who enter the new community under God's rule is no longer female, since it is not the work specifically of women, but also of men. ${ }^{23}$ Each person who comes to Jesus, becomes the womb for the $\Lambda$ ó birthing of new children. God loves the кó $\sigma \mu$ o $\varsigma$ so much that he gives his only coming-into-being $\Lambda$ ó $\varsigma_{\text {o }}$, so that everyone who believes, male and female, might conceive and bear eternal life in themselves, mediated by the $\Lambda$ ó ${ }^{\circ} \varsigma$ by an act of faith (the fluctuation between the Aorist and Imperfect symbolising the initial act of faith and the continuance in faith respectively). What is eternal partakes of the realm of ideas which, according to Philo's system, is male, but what partakes of that eternal life in John is neither (or both?) male and female in a new community that recognises neither male nor female, but mediates a new creation - to paraphrase Paul in Galatians 3:28 and 2 Corinthians 5:1.

22.See also the review by Cornelis Bennema (2011).

23.The gender implications of this have rightly been discussed in important studies by feminist scholars such as Adeke Reinhartz (1999) and Turid Seim (2005). Here they can only be noted and affirmed. 
Who are then the children of the new community of God's rule according to John? They are specifically those 'born not of blood nor of the will of the flesh (the female?) nor of the will of the andros (the male)'. This negates the carefully constructed world of binaries in Middle-Platonic philosophy as Philo interprets it and applies it allegorically to salvation history in the Hebrew Scriptures. Those who believe through Jesus who is the incarnate $\Lambda$ ó ${ }^{\circ} \varsigma_{\text {, }}$ and receive this $\Lambda$ ó $\gamma$ os when he comes into his own, are given power or authority

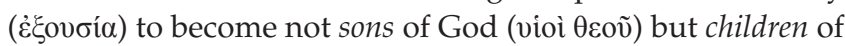
God ( $\tau \varepsilon \dot{\kappa} v \alpha \theta \varepsilon \circ \tilde{)})$.

For John, those who become children of God through impregnation and rebirthing mediated by the $\sigma \pi \varepsilon \dot{\rho} \mu \alpha$ $\theta \varepsilon$ ov, emanating from the $\Lambda$ ó $о \boldsymbol{c}_{\text {, }}$ are able to make the breakthrough to a higher plane of existence - something technically impossible, though longed for in Philo (see e.g. his well-known account of the biblical Melchizedek in Leg. all. 3.79-82). No one can see God according to Philo. John affirms that no-one has ever seen God or could ever see the Father (1:18), but the $\Lambda$ ó ${ }^{\circ} \varsigma$ mediates the vision of the glory of the Father (1:14), which was forbidden to Moses, indeed to all human beings (Ex 33:20; Jn 1:18), but is now revealed to those who have been birthed from above through the creative principle of the $\Lambda$ óyos to become children of God. 'He who has seen me has seen the Father' says Jesus in 14:9 and his community responds, 'We have seen his glory, the glory as of a father's only son' (1:14).

\section{Conclusion}

Reading John alongside Philo on the question of seed, conception and birthing has clarified his links with the conception of the $\Lambda$ ó $\gamma$ s in the Middle-Platonic milieu of the middle to the late 1st century. Of course we know little specific about the exact chronological, geographical and social location of the author of John's gospel, but John's use of the trope of the Logos and his sophisticated deconstruction and reconstruction of its Middle-Platonic schema as represented by Philo, represents a major shift in the evolution of the Judean cultural heritage. ${ }^{24}$ More than Paul, it facilitated the emergence of the Jesus movement as a world religion capable of embedding itself in very diverse cultures around the world. It propounds a view of Jesus that prioritises conception and birthing, creation and community, and vision of glory, rather than cross, death and suffering. While all are engendered naturally through and share in the attenuated possession of the seed of the $\Lambda$ ó ${ }$ s in their common material life, ( $\psi v \chi \eta)$ limited by its specificity in terms of flesh, time, language, ethnicity and culture, all may be re-engendered through the ideal seed of the $\Lambda$ ó making an act of faith in Jesus as the $\Lambda$ ó ${ }^{\circ} \zeta$ and share in a common ideal life ( $\zeta \omega \eta$ ) no longer restricted by the specificity of flesh, time, ethnicity and culture.

To return then to the questions we started with: Can metaphor be defined as 'contra-factual' in such a way that it

24.There is no conclusive evidence that John knew Philo, though it has been argued for example by Decharneux (1994). appears absurd if taken literally? Or if this definition is accepted, when does John cease to speak metaphorically? I have tried to problematize this and to show that the hearers, living with the worldview that underpins John's use of the 'metaphor' of seed and conception, would not have found the idea of a seed bearing much fruit by dying, absurd. It matches the Middle-Platonic worldview, influenced by both

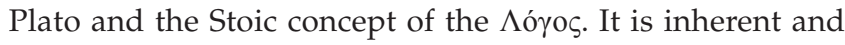

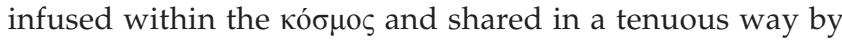
all material life that must die, but which passes on its life through the seed that is within it. Even spirit is understood as a material substance within the human body. Since Plato, there was also an understanding that some (philosophers) might turn their back on the material and ascend to contemplate the light of the $\Lambda$ ó ${ }$ s itself rather than its copies. Philo reflects this hope that virtuous human beings

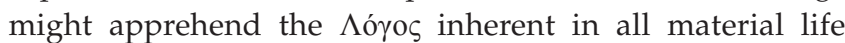
through the life principle in the seed of each life form. He also argues for the possibility of human transcendence to the ideal world through ascetic meditation on the Logos in his allegorical interpretation of Torah. In other words, for Philo there may be a hierarchical scale of possession of the seed of the $\Lambda$ ó

I have argued that John's use of $\psi v \chi \eta$ and $\zeta \omega \eta$ reflects this Hellenistic Jewish usage found in Philo and that he applies them to Jesus as the $\Lambda$ ó $о \zeta$ who creates all life as $\psi v \chi \eta \dot{\eta}$, the fragile material existence that yet contains and transmits life through the attenuated seed of the $\Lambda$ ó $\varsigma$ - a life sustained by the continuous work of the Father and Jesus (simultaneously as One) shining as light in the darkness. Yet, the inherence of the seed of the $\Lambda$ ó ${ } \varsigma$ in the natural order, offers to all the possibility of a new impregnation and birth through an act of faith in the $\Lambda$ ó $\gamma$ os into a new and qualitatively different

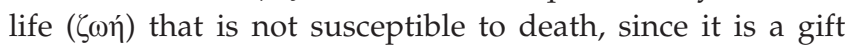
drawn from the very life of the $\Lambda$ ó $\gamma \circ \varsigma_{-}$- the ideal on which all the material types are modelled. There is no reason to believe that John understood this cosmic model as contra-factual or absurd. John opposes this adapted Hellenistic worldview to the alternative worldview of his Judaean opponents expressed in their interaction with Jesus so as to produce the Johannine phenomenon of sustained irony. Birth from the union of a man and a woman is not the opposite of birth through (water and) the Spirit and through faith in the Logos, but a higher plane of being. Controversies occur between the different philosophical schools in the Hellenistic world, but none of them see themselves as offering something contra-factual or absurd when they speak of the Logos bringing life to the world through its seed (though they may characterise their opponents viewpoints as such), or when they envisage the spiritual seed as somehow material in the human body like Galen. While Jan van der Watt has offered an intriguing and insightful attempt to read John through a web of metaphors of the family, it seems to me that his definition of metaphor needs to be modified to avoid the danger of imposing a modern literary model on the Johannine narrative that 'makes the rough places' inappropriately 'plain' to the modern reader. 


\section{Acknowledgements Competing interests}

The author declares that he has no financial or personal relationships which may have inappropriately influenced him in writing this article.

\section{References}

Barrier, J.W., 2014, 'Jesus' breath: A physiological analysis of $\pi v \varepsilon u ̃ \mu \alpha$ within Paul's Letter to the Galatians', Journal for the Study of the New Testament 37, 115-38.

Balch, D.L. \& Osiek, C. (eds.), Early Christian families in context: An interdisciplinary dialogue, Eerdmans, Grand Rapids

Barrier, J.W., 2015, 'Abraham's Seed: Tracing pneuma as a corporeal substance from Paul's writings to the Apocryphon of John', paper presented at the 17th International Conference on Patristic Studies, Oxford, 10-14th August .

Bennema, C., 2011, 'Review of Gitte Buch-Hansen, 2010, It is the Spirit that gives life': A Stoic understanding of pneuma in John's Gospel, De Gruyter, Berlin', Review of Biblical Literature (4), viewed 6 February 2017, from https://www.bookreviews. org $/$ bookdetail.asp?Titleld $=7689$ \&CodePage $=7689$

Berger, P. \& Luckmann, T, 1966, The social construction of reality: A treatise in the Sociology of Knowledge, Doubleday, New York.

Borgen, P., 2014, The Gospel of John: More light from Philo, Paul and Archaeology: The gospels, tradition, exposition, setting, meaning, Brill, Leiden.

Buch-Hansen, G., 2010, It is the Spirit that gives life': A Stoic understanding of pneuma in John's Gospel, Berlin, De Gruyter.

Cox, J.R., 1843, The writings of Hipocrates and Galen, Lindsay \& Blackiston, Philadelphia, viewed 6 February 2017, from https://archive.org/stream/56811 050R.nlm.nih.gov/56811050R\#page/n9/mode/2up

Dodd, C.H., 1953, The interpretation of the Fourth Gospel, Cambridge University Press, Cambridge.

Decharneux, B., 1994, L'ange, le devin et le prophete: Chemins de la parole dan l'oevre de Philon d'Alexanrie dit 'le Juif', Editions de I'Université de Bruxelles, Bruxelles.

Draper, J.A., 2000, 'Holy Seed and the return of the Diaspora in John 12:24', Neotestamentica 34(2), 347-359.

Draper, J.A. 2004, 'Practicing the presence of God in John: Ritual use of Scripture and the Eidos Theou in John 5:37', in J.A. Draper (ed.), Orality, literacy and colonialism in antiquity, pp. 155-170, Scholars Press/Brill, Leiden.

Draper, J.A., 2013a, 'Jesus' ancestors and African ancestors: A contextual reading of Matthew 1:1-18', in J. Grimshaw \& N. Wilkinson (eds.), Matthew: Texts @ context series, pp. 25-45, Fortress, Minneapolis.

Draper, J.A., 2013b, 'The metaphor of the Vine in John 15 and the Early Christian Tradition: Reflections on postcolonial critiques', in M. Lang (ed.), Ein neues Geschlecht: Entwicklung des frühchristlichen Selbstbewusstseins, pp. 53-80, Vandenhoeck \& Ruprecht, Göttingen.

Draper, J.A., 2015, "If those to whom the W/word of God came were called gods ..."-Logos, wisdom and prophecy, and John 10:22-30', HTS Teologiese Studies/ Theological Studies 71(1), Art. \#2905, 8 pages. https://doi.org/10.4102/hts. v71i1.2905
Draper, J.A., 2016, 'Darkness as Non-Being and the Origin of Evil in John's Gospel', in C. Keith (ed.), Evil in Second Temple Judaism and Early Christianity, pp. 122-141, Mohr Siebeck, Tübingen.

Engberg-Pedersen, T., 2010, Cosmology and self in the Apostle Paul: The material spirit, Oxford University Press, Oxford.

Geertz, C., 1973, The interpretation of cultures: Selected Essays, Basic Books, New York Goodenough, E.R., 1935, By Light, Light, Oxford University Press, Oxford.

Grillmeier, A., 1975, Christ in Christian tradition I: From the Apostolic Age to Chalcedon (451), transl. J. Bowden, Alden, Oxford.

Kowalski, B., 1996, Die Hirtenrede (Joh 10,1-18) im Kontext des Johannesevangeliums, Verlag Katholisches Bibelwerk, Stuttgart.

Leonhardt-Balzer, J., 2004, 'Der Logos und die Schöpfung: Streiflichter bei Philo (Op 20-25) und im Johannesprolog (Joh 1,1-18)', in J. Frey \& U. Schnelle (eds.) Kontexte des Johannesevangeliums: Das vierte Evangelium in religions- und traditionsgeschichtlicher Perspektive, pp. 295-319, Mohr Siebeck, Tübingen.

Liddell, H.G. \& Scott, R., 1968, A Greek-English Lexicon, rev. H.S. Jones \& R. McKenzie, Clarendon Press, Oxford.

Mooij, J.J.A., 1976, A study of metaphor: On the nature of metaphorical expressions with special references to their reference, North Holland, Amsterdam.

Mtata, K., 2015, 'African personhood and child theology', in U. Duchrow \& H.G. Ulrich (eds.), Befreiung vom Mammon: Liberation from Mammon, pp. 229-253, LitVerlag, Berlin

Nasimiyu-Wasike, A., 1992, 'Christianity and the African rituals of birth and naming', in M.A. Oduyoye \& M.R.A. Kanyoro (eds.), The will to arise: Women, tradition and the Church in Africa, pp. 40-53, Cluster, Pietermaritzburg.

Nestle-Aland, 2013, Novum Testamentum Graece, 28th edn., Institute for New Testament Textual Research, Münster.

Osiek, C., 1996, 'The family in Early Christianity: "Family Values” revisited', Catholic Biblical Quarterly 58, 1-24.

Rabens, V., 2012, 'Johannine perspectives on ethical enabling in the context of Stoic and Philonic ethics', in J.G. van der Watt \& R. Zimmermann (eds.), Rethinking the ethics of John: 'Implicit Ethics' in the Johannine writings, vol. 3, pp. 114-139, Mohr Siebeck, Tübingen.

Rabens, V., 2013, The Holy Spirit and ethics in Paul: Transformation and empowering for religious-ethical life, 2nd edn., Mohr Siebeck, Tübingen.

Rahlfs, A. \& Hanhart, R., 1949, Septuaginta: Id est Vetus Testamentum grace iuxta LXX interpretes, rev. edn., Deutsche Bibelgesellschaft, Stuttgart.

Reinhartz, A., 1999, “'And the Word was Begotten": Divine Epigenesis in the Gospel of John', in A. Reinhartz (ed.), God the Father in the Gospel of John, pp. 83-104, SBL, Atlanta.

Runia, D.T., 1981, 'Philo's “De aeternitate mundi": The problem of its interpretation', Vigiliae Christianae 35(2), 105-151.

Runia, D.T., 1986, Philo of Alexandria and the Timaeus of Plato, Brill, Leiden.

Seim, T.K., 2005, 'Descent and divine paternity in the Gospel of John: Does the mother matter?', New Testament Studies 51 (3), 361-375.

Stenning, J.F., 1953 [1949], The targum of Isaiah, ed., transl., Clarendon, Oxford.

Van der Watt, J.G., 2000, Family of the King: Dynamics of metaphor in the Gospel according to John, Brill, Leiden.

Van der Watt, J.G., 2006, 'Ethics alive in imagery', in J. Frey, J.G. van der Watt \& R Zimmermann (eds.), Imagery in the Gospel of John, pp. 421-448, Mohr Siebeck, Tübingen. 